\title{
2 Women, Men, and the Arab Family
}

\subsection{Arab Marriage is Child Rape}

Most certainly, French and Arabs have different practices and mores. While the consummation of marriage with a prepubescent girl is a crime for the French, it is customary for the Arabs. That is why young girls get married at an age when young French girls still play at being a bride.

Impatiently watching the childlike movements of their daughters, Muslim fathers calculate how many duros ${ }^{48}$ they will be worth because, unlike the French who only consent to marry a woman who brings them money, the Arabs, instead, are obliged to give some in order to marry. What constitutes a Muslim marriage, what makes it valid, is the dowry paid by the husband as the bride price for the woman.

In cities, the woman's dowry is calculated in cash (in duros); in the tent, in sheep, camels, and palm trees. In Saharan oases, the black woman's bride price consists only of jewelry, belts, tulle and cotton rolls. An ordinary woman is worth between thirty and fifty francs. A woman who knows how to weave a burnous is valued between three and eight hundred francs. A twelve-year-old is priced for her figure, a twentyyear-old for her skills.

At the beginning of the occupation, Arab women kept as hostages were exchanged for horses or auctioned off like beasts of burden. In ancient Greece, women were traded for oxen; this is why the Iliad called them "finders of oxen." In the African South and in Asia, the female sex replaces cash, as do pearls. In Afghanistan, the delivery of several girls is compensation for a murder and that of a woman for a wound.

Depending on her gentleness and her family's rank, a little girl is worth between three hundred and a thousand francs. Suitors compete for Muslim women trained as teachers and pay from one to three thousand francs for them. The prettier they are the surer young Arab girls are to be bought by an older husband who can afford to pay dearly.

The sale of a Muslim woman is the occasion for haggling between the father and the future husband. The object of contention is not informed of the business before it is concluded. There are seven-year-old girls who draw straws in order to learn to which of the men who bought them they will belong. This proves that in this trade bad faith is not excluded.

In fact, every day Algerian courts hear scandalous revelations and complaints from men who have paid for a woman who was then carried off by another. A great to-do was made in France about the adventure of a young Kabyle teacher, Fathima. Sold by her father for seven hundred and fifty francs to a man named Rhamadan, she

48 Units of currency; ancient Spanish silver coins.

(cc))BY-NC-ND $(C) 2014$ Hubertine Auclert

This work is licensed under the Creative Commons Attribution-NonCommercial-NoDerivs 3.0 License. 
then married a young man after her own heart, the teacher Ibrahim, but was claimed by her first buyer. In deference to Koranic law, Mekla's juge de paix decided in favor of Rhamadan, and it took the pressure of French public opinion, deeply moved by this barbarous custom, to force Tizi-Ouzou's tribunal to annul the juge de paix's decision, free Fathima from the contract agreed upon by her father and Rhamadan, and allow her to live out her perfect love story with the teacher she married.

Let us not forget that Fathima and Ibrahim belonged, however remotely, to the academic world, that their superior, M. Jeanmaire, was interested in their odyssey and had brought it to the public's attention. Without the public indignation aroused by these circumstances, Fathima would have been obliged to leave her second husband whom she loved to go and live with the first one whom she did not know. Clearly, our French tribunals commonly accept Arab anomalies.

However eloquent and imploring ordinary victims can be, their desperate voices move neither the public nor the judges. I have seen some of them wring their hands, writhe on the floor, scream, and bite anyone who came close, when they heard intimidated French judges treat them according to Muslim customary law in outright contradiction with our French law.

Too often judges annul freely concluded marriages in order to deliver a woman to the man who bought her when she was a child. Indeed, some French magistrates even deliver young girls to the men who bought them before they were born! A few years ago, in Ben-Mensour, a father sold his yet unborn daughter. When the little one entered this world, he wished to cancel the contract, but the court decided in favor of the planned marriage and the little girl, sold before her birth, belonged to her purchaser. According to the inhabitant who told me this story, the lawsuit cost seventeen thousand francs.

The fathers, eager to profit from their daughters, do not wait for them to be of age to marry them off. To mask this crime against nature, they make sure to tell the husband to wait four or five years after the marriage before exercising his conjugal rights. The child is nonetheless at the mercy of a man who has no outlet for his passions, who thinks that the little girl he paid for is his possession, and often the little girl has no chance to grow into a real woman.

When such glaring facts reach the ears of the courts, the criminal parents and the man who inflicted not marriage but rape on a child find convenient witnesses who testify to their good faith and they are acquitted. The Cour d'assises ${ }^{49}$ of Algiers just acquitted a husband from Takement, Medja Iddir ben Mohamed, who raped his nineyear-old ${ }^{50}$ wife after chaining her down.

To put an end to these marital rapes, the law forbidding girls to be contracted in marriage before the age of fifteen should be applied in all French territories. If women

49 Court composed of judges and a jury.

50 Author's italics. 
shared power in France, they would not accept that a law permitting child rape exist in a land under French rule. Men tolerate this crime because of solidarity with those who profit from it.

Poignant dramas occurring in the gourbi ${ }^{51}$ or in the tent are sometimes revealed: I have seen a nine-year-old girl, emaciated and covered with burns, brought before a judge. Her husband, an old man, said she fell into the fire during an epileptic fit. Everyone knows the causes of such nervous episodes so frequent in young Arab wives.

The atrophy they suffered during childhood makes most women small, delicate, and sickly while the men of their race are tall and strong. Will French law always give in to the Koran? Won't the Republic give assistance to the young victims of Muslim debauchery?

According to Koranic law, no woman can refuse marriage. Fathers have the right to impose it on their daughters. Guardians or cadis (judges) have the power to force orphans to marry.

A Muslim woman keeps her name when she marries. Messaouda bent (daughter) Djaffar remains Messaouda bent Djaffar after her marriage to Aïssa ben (son) Lakdar. One would not know her if she changed name as often as she changes her master. She wisely keeps her own, which is not the case for us, and instead of annihilating her personality like a French woman, she enlarges it; with marriage she acquires a sort of civil and economic emancipation. Not until she marries can an Arab woman decide what to do with herself and her fortune; but from her marriage day on she can manage and enjoy her personal property. She can even testify against her husband without any authorization.

Separation of property is the common law between Muslim spouses. A wife is not bound to spend anything for the household, she does not have to contribute anything, since the first condition required of a man who wants to contract marriage is to be able to support and feed each of the women he marries. However, Arab men often ignore the Koran and exploit their wives instead of supporting them.

Even though a Muslim bride has received a dowry from her husband, on her wedding night she asks him for "the right of first meeting." Depending on his means, the husband gives her a coin or a bank note. This was the custom in France during the early times of our history. Didn't Clovis ${ }^{52}$ marry Clotilde with a golden sou and a silver denier ${ }^{53}$ A husband was supposed to buy his wife with these two pieces of money.

Prohibitions relating to Muslim marriage are numerous. There cannot be blood kinship between the engaged couple or milk kinship because marriage is forbidden

51 Poor Arab dwelling; Algerian word.

52 King of the Franks from 481 to 511.

53 Old French coin. 
between children who have suckled at the breast of the same nurse. M'zabites must marry in their tribal area, emigration is forbidden to them. Muslim women may only marry Muslim men while Muslim men may marry women of any race and religion.

\subsection{Arab Nuptials}

In front of a cadi and two witnesses, the future husband says to the fiancée's father, "I count out the sum or the remainder of the sum (advances have often been given) agreed upon to buy your daughter." And the father answers, "Here is my daughter, make her your wife." The marriage is thus concluded. The sale of a young woman is accomplished as unceremoniously as that of a heifer.

Entertainment starts soon afterwards; a feast takes place - in the desert the choice morsel is a female camel's hump - and after eating, one examines the presents. The gifts received by the bride are spread on carpets, unlike in Europe where they are exposed on the living room's furniture. Everywhere one takes the same care to show them off.

Finally, the husband surrounded by horsemen pretends to steal his wife; he lifts her onto a mare harnessed with bright fabrics or into a palanquin carried by a dromedary. The onlookers make room for the procession: first handsome, triggerhappy horsemen; then, on minuscule African donkeys, children wearing a bright white gandura ${ }^{54}$ and a red chéchia. ${ }^{55}$

Negroes, castanets in their hands, dance wildly in the middle of the street: they wriggle, turn, crouch, rise up, and jump with a devilish furor as though touched by a magician's wand. Then come drums, musicians, and women on foot, in a long row, who open their white haik to let out a resounding scream, "yu! yu! yu!"

The nuptial celebration continues in the marital home where the husband receives his spouse like a queen. The young woman, who has expressed her consent by her silence, still seems to have lost her tongue. Propriety forbids her to speak during the entire wedding's rituals. In some regions, in Ghadamès for instance, a bride must stay absolutely mute for the first seven days. Her mother speaks for her. She publicly overwhelms her with advice, "Be a slave to your husband if you want him to be a servant to you. Prepare his meals carefully and surround his sleep with silence, because hunger makes for bad temper and insomnia for bad mood."

The crowd of onlookers squats and feasts. Everyone who comes in, however poor, however unknown, is welcome, a guest of God who partakes of the wedding feast. After eating, there is laughter, joyous calling out to one another. Negroes tell jokes that delight the crowd.

54 Shirt; sleeveless tunic worn under the burnous.

55 Fez. 
An Arab wedding is at once a tournament, a concert, a comedy, and a dance. At night, while the rockets work wonders and the laughter and bravos burst like fireworks under the open sky, the bride and groom, having retired, often talk for the first time.

The door to the newlyweds' room or tent is soon opened; people rush in, scrambling to be the first to see the bride just out of her husband's arms, her hair undone, her clothes wrinkled, looking embarrassed and... disillusioned. She is sitting on a carpet, admired, congratulated. Nobody neglects to make loud remarks about her countenance. Happily, pleasure is stronger than curiosity: the vivacious and joyous crowd rush toward the musicians. The almahs ${ }^{56}$ dance starts again; finally, unable to keep still, some face each other, some try steps and jumps that one would try in vain to find at our French cities' balls.

Even though the husband retains the right to forbid his wives from eating garlic and indulging in debilitating occupations, Muslim marriage is more advantageous than French marriage because, far from losing her rights, the wife acquires some and instead of giving a dowry she receives one. On the other hand, this marriage is not based on consent; it nearly always takes place over the young woman's objection and involves polygamy.

\subsection{Polygamy}

A military court ${ }^{57}$ in Oran recently acquitted Rochia, wife of Mohamed-Ould-Saïd, chief of Douar Marnia. After a scene of jealousy, this woman came to blows with Saïd's second wife, Aisha, and killed her outright with a stick. The proceedings revealed curious details about polygamy, the cause of this tragedy.

Polygamy, which forces women, condemned to put up with it, to use the sword or poison to eliminate a rival, leads men to homosexuality. Because women - rare in Arab country to begin with since they are twenty-two percent fewer than men are snatched up by those who can afford to buy them, it is often impossible for the poor to have a wife; so they take... men! Some are even occasionally caught behind a tuft of lentisks in criminal conversation with... a she-goat or a ewe! These primitive beings should not be accused like ultra-civilized people who look to pederasty as a refinement of debauchery. If they resort to unnatural means of satisfying their amorous instincts, it is because the polygamists make a clean sweep and cause a dearth of women.

It is known that, under of Koranic law, the Muslim man can display the most dissolute habits. Possessing a large number of wives makes his opulence undisputable; so he spends a fortune on wives as Europeans do on horses. First, he marries over and over again! Then he saddles himself with concubines, to the point of being unable

56 Almahs are dancers and singers.

57 In military territories, military tribunals replace civil courts. (author's note) 
to maintain his household expenses. Then, to lighten his obligations and still carry on his amorous fantasies, he ousts wives and concubines and takes on some others. The renewal of his female personnel is his greatest entertainment. "Woman has been created for man's pleasure," say the Arabs, "how could only one wife amuse a man his whole life? Polygamy and repudiation are necessary."

According to Mohammed's dictates, each wife of the same husband should have her own house, but that is not the case; usually, the husband and all his wives live in total promiscuity in order to avoid the expense of separate lodgings.

The Prophet, appropriating a fifth of the loot and a fifth of gifts and presents, was able to possess at the same time, thanks to his considerable fortune and disregard for the law, seventeen legitimate wives and provide a certain comfort to each of them plus his eleven concubines. Unfortunately, all Muslims do not have as high an income as their religion's founder; most often, their home is a tent separated in two parts by a large curtain. On one side are all the women (the Muslim who admits to four wives usually has six), on the other side is their husband lavishing his caresses on the favorite of the day.

All peoples have practiced polygamy. Israel's kings were polygamists. Salomon had sixty legitimate wives and eighty concubines. The Franks too were polygamous. Charlemagne had eight wives. Historians say the emperor fought battles against them in Aachen's mud huts, but despite his iron gauntlet, while victorious elsewhere, he was often vanquished there.

Mohammed was not any happier with his seventeen spouses. When he did not trade blows with them, he traded insults; he was ceaselessly obliged to call upon God to curb their irreverence. One day his fifteenth wife, Zeinab, served him a poisoned lamb shoulder.

"Why," asked Mohammed, "did you commit this crime?”

"I wanted to ascertain that you really were the Prophet," answered Zeinab, "whether you could protect yourself against poison or, otherwise, to deliver my country from an impostor and a tyrant."

His favorite, Aisha, was so unfaithful that, in order to silence his scandalized contemporaries, he put these words in chapter 26 of the Koran: "Those who would accuse a woman of adultery without producing four witnesses will be punished with eighty lashings." Aisha's virtue, besides the fact that she was a remarkable woman, was no longer in doubt after this verse. Even though he found it impossible to live in harmony with so many legitimate or illegitimate spouses, Mohammed never renounced his passion for the female sex. "The two things I like most in the world," he often said, "are women and perfume."

All the chorfa (religious leaders) are polygamous like Mohammed. Morocco's former sultan had hundreds of wives; a new spouse entered his harem every Friday. Norodom, king of Cambodia, gives a utilitarian aim to polygamy: he assigns each of his five hundred wives an occupation in his palace; the luckiest ones are comedians or dancers, the others are cooks, dressmakers, etc. For Arabs too, the other women are 
servants of the momentary favorite. But today's chosen one cannot be sure that she will not be repudiated tomorrow, so mercurial is the Arab.

Civilization drove out polygamy as against nature and contrary to human dignity. So why did monogamous France, when conquering Algeria, let it subsist there? It is strange that having several wives, though condemned in France, is permitted on our French African soil. If French women voted and legislated, their African sisters would have long since been delivered from the offensive polygamy and intolerable promiscuity with co-wives.

It is when one sees the prejudice of race dominate everything in Algeria that one understands the absurdity of the prejudice of gender. The Arab race, so handsome and so talented, is absolutely despised by Europeans who rarely are as handsome or exhibit as many natural aptitudes as do the Arabs. And look at this contradiction: the victorious French say to the Muslims: "I despise your race, but I make my law subordinate to yours; I give precedence to the Koran over the Code.” The French allow the Arabs to practice the polygamy that they forbid themselves. To mask their faulty logic, they declare that the Africans have needs unknown to Europeans and that it is to satisfy these needs that they allow them to have so many wives. If polygamy is a necessity for Arabs, then the rich alone can be satisfied; so then how can the poor, much more numerous than the rich, bear the pain of their deprivation?

I have seen with my own eyes examples that contradict this assertion: Arabs, healthy while they had one wife, became weaker and lost their health as soon as they had several. Polygamy not only hastens physical decrepitude, it brings with it intellectual degeneration. Concentrating their cerebral activity on bestial instincts, it destroys their intelligence and atrophies their brain.

Getting closer to death and preparing for the end of his race, is the polygamist any happier? I have questioned quite a few men about this matter; they have all confessed to me that having several spouses engenders domestic disputes and that the state of war is permanent in the house of the man with several wives. Mohammed, despite his many carnal desires, bitterly related the complaints showered on him by his numerous wives and concubines. At the time of Gladstone's golden wedding anniversary, the late Persian shah, Nasr-al-Din Shah, who had nineteen legitimate wives and two hundred concubines, repeated to whoever listened, "It is better to live fifty years with one woman than one year with fifty."

It should be known in France that polygamy deeply offends the Arab woman. The young wife of a polygamist nearly always responds to her husband's first compliments with insults. It is the very weak expression of her horror and disgust for what she calls the "conjugal kennel." Many Arab women repeat all day long to their husband that they cannot willingly live with a man who has several wives, and only remain in his house by force.

In Muslim country, when a newlywed enters the door with his new wife, it is not rare to see the official first wife leave by the window and run to her parents. 
Reconciliation is attempted; the polygamist claims that he brought a second woman to his house in order to have her do his mother or sister's chores without pay. When the cadi forces the woman, outraged in her dignity, to go back to the conjugal house, a terrible war breaks out between the wives. These rivals, who share in turn the master's blows and kisses and who call each other "my insult," work to have the other ousted and repudiated. "Two women spy on each other; three, four wives of the same husband spy even more." In this household of four or eight there is no love but a fierce jealousy that engenders crime and almost makes it inevitable in this pernicious atmosphere.

Children do not escape this jealous furor; to each baby of a polygamous family his father's other wives are wicked step-mothers who often resort to more than just torture. Just the other day, a young Arab woman held between her legs a handsome two-year-old cherub, her rival's child, and slit his throat like that of a kid. These stepmothers of sons and daughters of the same father usually act surreptitiously and even if they are suspected, nobody can convict them of having crippled or blinded their rival's child.

Does polygamy at least populate Algeria's immense territory? No, because polygamy does not increase but reduces the number of births. Large Muslim families do not exist; despite his wish for paternity, the husband with four wives does not have more children than the European with only one. Two linked reasons combine to limit reproduction: the polygamist's excessive brutality and the woman's sterility due to the atrophy she suffered during childhood. Because polygamy is practiced without women's consent and brings no benefit to either the individual or the collectivity, the following petition asked that it be abolished:

"Messieurs the Deputies, Messieurs the Senators,

I would like to call your attention to the plight of Arab women who, with France's tacit permission, are so barbarously treated.

The Arab woman sold to a husband as a child is sequestered by that husband in the "conjugal kennel" with her co-wives and then repudiated without cause to make room for another.

We have permitted the Arabs to keep their laws, their mores, and their language for too long. Don't you think it is urgent to make them children of the Republic, to educate them, and to assimilate them to the French?

I beg you, Messieurs, to replace barbarism with civilization on our African soil by ordering the abolition of polygamy to which Arab women are subjected by force and which is offensive to the whole female sex. I also ask you to forbid the marriage of young prepubescent girls.

Child rape under pretext of marriage, plurality of wives, and their sequestration in matrimonial prisons are laws and practices against nature; they hinder the increase of population instead of favoring it and impede the desirable fusion between the Arab race and ours.

The Republic - unless it contradicts its own principle - cannot keep encouraging polygamy and marriage of prepubescent girls on one side of the Mediterranean and punish it on the other. I hope, Messieurs, that you will be inspired by civilization's interests and will abolish the inhuman laws that govern the majority of French Africa's inhabitants. 
This petition triggered comments in the press. "Now," said some newspapers, "here comes a French Algerian woman to help the senators! It is inexcusable that she has not seen anything for she was in a position to observe everything when she lived in Algiers, Laghouat, and the southern Oran region." "Polygamy is in our mores," affirmed some chroniclers.

If polygamy is in our mores, it is not in nature. Thus, women, less sophisticated than men and closer to nature, are absolutely monogamous, and are even monogamous when they are morally demeaned: the "party girl" always has a sweetheart and the lowest prostitute takes a pimp in order to have her own man.

Far from moderating passions, polygamy exacerbates them; the polygamist is even much more unfaithful than the monogamist. He is legally accustomed to change.

In any case, if polygamy is such a good thing, if Arab men want to go on having several wives, the most basic equality demands that Arab women have several husbands, as they did before Mohammed. Muslim men being much more numerous in Algeria then women, it is polyandry and not polygamy that should be practiced. Polygamy is for all or else, "Down with polygamy!"

The president of the Chamber of Deputies - to whom my petition was forwarded - conveyed to me the minister's unfavorable decision about the Arab woman's juridical and social condition. "It does not seem possible," says the minister of Interior, "to give satisfaction to the petitioner's wishes, at least for the moment, as Algeria's governor-general remarked. The Arab woman's situation could not be modified without altering the Muslim personal and inheritance status that has always been respected by the Algerian legislation. It would actually be foolish to place such a serious question under consideration: besides the obvious impossibility of reaching a practical solution, it would provoke within the native population, already preoccupied with projects of reform, an agitation which would be better avoided."

The minister of Interior is more Muslim then Mohammed himself. While he invokes an imaginary danger, a good Muslim, Kassim-Anim Bey, member of Cairo's Court of Appeals, is calling for a law forbidding polygamy and repudiation, and for giving women an education, letting them be independent and free to choose their husbands.

Well! Ideas are in the air, progress pushes men forward, so why would only those conquered by the French Republic remain stuck into their old errant ways? Should Muslim Algeria hold the status quo while everything around it is moving forward? The statutes invoked to refuse modifying the Arab woman's situation have been violated many times by the administrators when they wanted to bar the natives or exact a ransom from them. In any case, these statutes, to which the minister seems to attach such importance today, have been disregarded by the Arabs themselves who, ignoring agreements, have not ceased to be belligerent and try to recover their independence since Algeria’s annexation. 
France, under the cover of its civilizing mission, has dispossessed Arabs of Algeria's territory, and now it claims its respect for the barbarism of the vanquished in order to keep them outside the very civilization in the name of which it conquered them! This is unimaginable!

It is not impossible, as one would believe, to reach a solution suppressing polygamy in the Muslim world. I have studied this matter. I found out that many Arabs too poor to marry have no other alternative than unnatural means to satisfy their sexual appetites. Most others are monogamous and frequently resort to divorce. So, in fact, the number of Arabs practicing polygamy is small, and educated men with only one wife are not included in this number. An Arab municipal councilor visiting me recently in Paris said to me, "It is already rather difficult to please one woman, how could one please several?”

As for our native sisters, as soon as they learn about our life, they feel disgust for their condition of "herd-women" and refuse to go back to an environment where they are forced to put up with polygamy and sequestration.

Despite the Koran, Tuareg women have forbidden polygamy and one does not find in their tribes any instances of men with second wives.

As for the momentary unrest which will resurrect the Arab race's noble past and set it on the path to progress, it is childish to try to avoid it. This unrest will inevitably take place at the time of assimilation. Polygamy, an obstacle to the fusion of our two races under one law, must be sacrificed to French unity.

Few Westerners are really monogamous. They have successive and sometimes multiple liaisons, but at least this polygamy is hidden in monogamous countries. If a man took it into his head to have his wife meet his mistress, he would be called a heel by his fellow-men. Well, Arab women have those same delicate feelings understood by European men and they should be respected. There is no sky under which a woman who gave her heart wants to share with others the man she loves.

\subsection{Repudiation}

The vultures who do not want the Arab prey to escape them by becoming French pretend to fear uprisings and unrest in order to abstain from curbing the depressing sexual excesses of the conquered. While the exhausted polygamist fights in the "conjugal kennel" with the many wives-workers who enable him to be majestically lazy, he does not think of defending either his liberty or his property. "Out of there, polygamist, make room for me!” thinks the colonizer. Those who cannot exterminate the Arabs are delighted to see them emasculated by their multiple wives and the rapid change of their female personnel through the little game of repudiation.

In pre-Islamic times, Arab women had the right of repudiation, but the founders of religions are like the makers of laws, partial to their own sex. Mohammed reserved the 
privilege of repudiation for men and took it away from women. A man may rightfully repudiate his wife whenever he wants to without having to give other reasons than his whim. Repudiation occurs without procedure. It is an intimate performance accomplished by the husband's thought and consecrated by his mouth with words along these lines: “Go away! I give you to yourself! You have free rein!” In the matter of repudiation, the courts only intervene in case of disputes.

The husband who has repudiated his wife twice with the formula mentioned above may marry her again in return for a new nuptial donation; but if he has offended her with these outrageous words: "You are like pig's flesh for me," he cannot marry her again before she has been married to another man. There is only one case that annuls or rather defers the third repudiation: when it was pronounced during the woman's menses. You see how uncertain the Muslim woman's condition is. Today she is a wife; tomorrow she will be repudiated, driven out from the tent or the house where she lived. No Muslim woman exists who has not been repudiated at least three times. This custom is so widespread that it does not even discredit her. However, there is no reciprocity; if her husband displeases her, she cannot use repudiation to get rid of him.

For the polygamous Muslims, when a woman no longer pleases or when her work does not bring in enough to her husband, there is no torture he does not use before resorting to his right of repudiation. Some husbands swing the woman they no longer want over a plank spiked with nails, so that her legs and back are covered with blood. Others contrive to have her bring her chest forward and then squeeze her long breasts in a half-opened door. This savagery takes place under the aegis of our civilizing government! What are we waiting for to put an end to this barbarism? That people more diligent and clever than we are impose their laws on the Arabs!

\subsection{Divorce D8 $^{58}$}

"Let them give us lizards for husbands instead of polygamists!" shout handsome divorce seekers in the tribunals. If one marries often in a Muslim country, one divorces nearly as often. It is because Arabs are not yet subjected to the prejudices that force civilized people to voluntarily put up with torture. When they are unhappy in marriage, they very wisely separate.

58 Several legal systems were at play: the French colonial system, and the other, i.e. the religious, Koranic system which often applied customary law. 
Men have several ways to break the conjugal knot: they can dissolve the marriage by different procedures: the tala ${ }^{, 59}$ the $i l a,{ }^{60}$ or the lia. ${ }^{61}$

They rarely use the moubara, divorce by mutual consent, which doesn't cost anything to the wife. The husband sometimes asks for such a large sum of money to give his wife her freedom that no buying suitor wants to pay the price, and the wifemerchandise then remains available. In general, the husband accepts a separation only when his wife proposes a sum as compensation, which is the khul divorce in which the wife divests herself so as to pay her husband the ransom of her freedom. Price plays a role in this divorce; the woman's honor requires that she does not get her freedom for too low a price; so she leaves part of her dowry, if not all of it, to the husband from whom she wants to be freed.

In the Arab world, a woman who has ceased to please must reimburse the sum the man paid for her. The cadi lends the husband a hand: he only pronounces the khul divorce, so when the Muslim woman has a case that can be decided by the authority of the law, she prefers to appeal to the impartiality of French tribunals. These can automatically pronounce the divorce against the husband's will if he mistreats his wife, does not support her sufficiently, or is unable to perform his conjugal duties. This is the case most often alleged by the women.

In Algeria, doctors complain of being relentlessly pursued by Arab women who want them to certify that their husband is impotent. It is not rare to see these women start a divorce procedure, with or without certificates, asking the French tribunals to grant them a few thousands francs for damages because their spouse has not been a regular husband for some time.

The Muslim woman who asks the court for a divorce exposes her grievances to the judge who, after hearing her, puts her and her husband in adala (observation) for a week with a reliable person. At the end of that time, their monitor writes a report declaring which of the pair is in the wrong. As for the judge, he gathers the facts, and when he is sufficiently enlightened, he pronounces the divorce.

It is during their divorce procedures that Arab women really show what they are. Their sheepish husbands hang their heads while the women display such eloquence one would take them for the resurrected great speakers of pagan Arabia. They vehemently protest the plurality of wives. They declare that they prefer prison to the harem. "Let them give us lizards for husbands instead of polygamists!" Being born free, Muslim women fear neither beatings nor imprisonment. That is why, if they are unhappy, they want to be out of their marriage as soon as they enter it. The only question for them is how to leave their marriage with their pride intact without losing money, even if it means spending some.

59 In Muslim law, it means to untie the matrimonial knot by articulating a word denoting divorce three times; it is the repudiation procedure described above.

60 An oath the man takes to abstain from sexual intercourse with his wife for four months and carries it out.

61 Procedure used in cases of accusation of adultery. 
The Arab woman never bargains when she wants to free herself. Often, before obtaining her divorce, she is impoverished by minor judicial clerks, if not by the judges themselves. Intelligent Muslims who watch what goes on inside and outside the courtroom believe that all French consciences are for sale, so they persistently solicit and pay for the civil servants' connivance. Algiers' Cour d'assises condemned Cadi Ali M... to a four-month prison term for attempting to bribe an appraiser. He had offered him an envelope containing a thousand francs saying "for coffee!"

Arab justice, where without expense, without waste of time the case is heard and judged forthwith by the cadis, is as expeditious as French justice is slow and onerous; but despite days of waiting and considerable cost, the quibbling Arabs are constantly in court. It is true that tribunals sometimes show pity for these dispossessed people whose instinct pushes them to try anew. Much before judge Magnaud ${ }^{62}$ became $^{2}$ famous, a humble juge de paix acquitted a poor Arab who, having not eaten for five days, stole a goat and sold it for five sous.

Muslim litigants rely much less on their rights than on their purse to win their cases; as soon as they have any problems with the law, they want to get everybody on their side, so they offer money to the judges and their ancillaries. Women act like the men; when they go to court to obtain a divorce, if they cannot bribe the judge they will try to corrupt his wife.

On a day of Muslim hearings, a pretty Mauresque was introduced to me. After making sure that I was alone and that doors and windows were closed, she approached me and with a thousand signs of affection handed me some papers. While I was reading she kissed my hands and clothes, lay down at my feet and put her lips to the hem of my dress. She suddenly got up and took handfuls of duros from a bag hidden under her melhfa (dress) and, putting a finger over her mouth, handed them to me. When I indignantly refused to let her buy my intercession with the judge, my husband, her surprise was unimaginable.

A Muslim can divorce the same woman twice and take her back legally after three months and ten days. If he divorces her a third time, he will not be allowed to take her as his wife before another man has married and repudiated her.

When judges ask the Arabs appearing before them how old they are, they often answer, "We are like sheep, we have no age." An oath is never taken in court but it is accepted when it is called upon a venerated marabout ${ }^{63}$ or upon the Prophet's banner floating above incense burners on a Friday before noon in a mosque.

The best situation for well-to-do Arab women is to be divorced or widowed; then only are they free to participate in the life of the outside. They preside at meetings where matters of tribe and race are discussed. In this country where poets, a sort of

62 Paul Magnaud (1848-1928) was famous for having acquitted a woman who stole bread.

63 Holy man, saint of Islam; tomb of the saint. 
troubadours, go from douar to douar, a woman's recitations about love and gallantry do not discredit her but give her prestige. It is said that such women have legions of platonic adorers. 